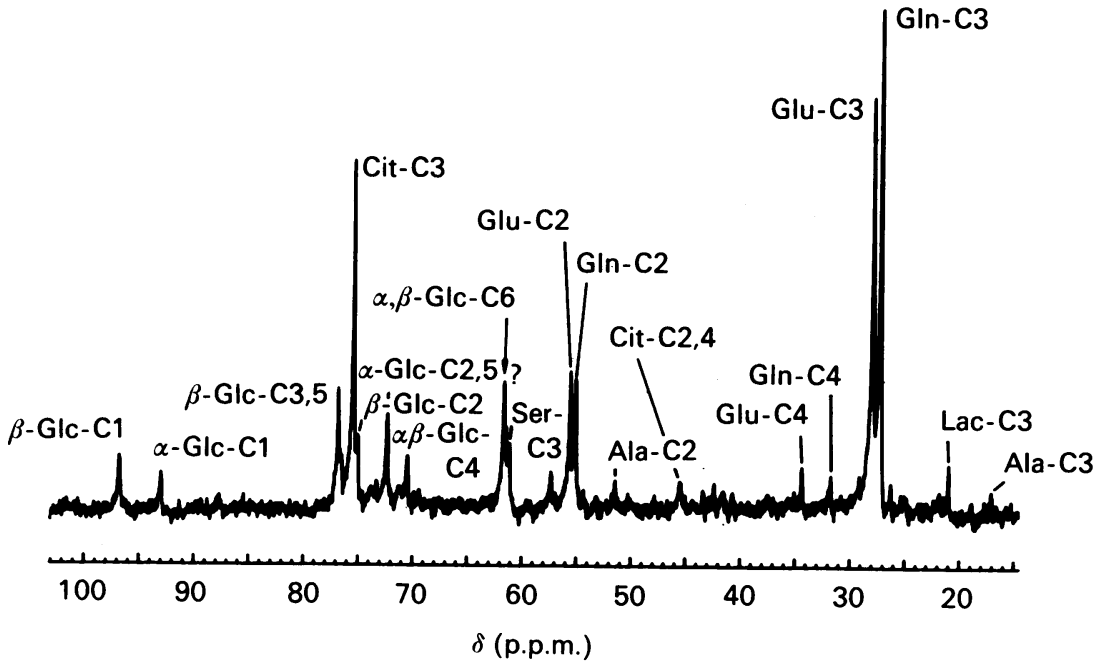

Fig. 1. 100.6 $\mathrm{MHz}{ }^{13} \mathrm{C}$-n.m.r. spectrum of a $\mathrm{HClO}_{4}$ extract of rabbit renal proximal-tubule cells incubated with $3.5 \mathrm{mM}-\left|3-{ }^{13} \mathrm{C}\right| c i t r a t e$

The assignment of $\alpha, \beta$-glucose C-6 is corrected compared to Fig. 1 of [5].

of a citrate concentration of $3.5 \mathrm{~mm}$, whereas under normal conditions the citrate concentration is in the range of $0.5 \mu \mathrm{M}$. This implies that under our experimental conditions in the renal proximal tubule cells the reversed citrate synthase reaction occurs to decrease the actual citrate concentration. However, a low activity of citrate cleavage enzyme in rabbit kidney tissue has been described for 30 years [8].

Arnold W. H. JANS

Max-Planck-Institut für Systemphysiologie, Rheinlanddamm 201, D-4600 Dortmund 1, Federal Republic of Germany

1. Cohen, S. M. (1987) Biochemistry 26, 563-572

2. Cohen, S. M. (1987) Biochemistry 26, 573-580

3. Cohen, S. M. (1987) Biochemistry 26, 581-589

4. Malloy, C. R., Sherry, A. D. \& Jeffrey, F. M. H. (1988) J. Biol. Chem. 263, 6964-6971

5. Jans, A. W. H., Winkel, C., Buitenhuis, L. \& Lugtenburg, J. (1989) Biochem. J. 257, 425-429

6. Jans, A. W. H. \& Leibfritz, D. (1989) NMR Biomed. 1, 171-176

7. Katz, J. (1989) Biochem. J. 263, 997

8. Srere, P. A. (1959) J. Biol. Chem. 234, 2544-2547

Received 1 August 1989

\section{Correction: isoprenaline-induced}

transcription of $\mathbf{4} \beta$-galactosyltransferase is inhibited by both cycloheximide and actinomycin $D$ in rat parotid acinar cells

In a paper in this journal I reported [1] that the cDNA clone used to measure transcription rates in cultured primary rat parotid acinar cells was for $4 \beta$-galactosyltransferase [2]. Isoprenaline, a $\beta$-adrenergic-receptor agonist, caused an increase in steady-state amounts of this mRNA along with an accompanying increase in galactosyltransferase enzyme activity. Furthermore, increased enzyme activity was dependent on gene tran-

scription and mRNA translation since inhibitors of either biosynthetic pathway eliminated the increased level of galactosyltransferase protein. However, more-recent experiments on the expression of this clone, as well as DNA sequence data, support the conclusion that the cDNA is not in fact coding for galactosyltransferase but for a modifier/effector protein of the enzyme. Expression in Escherichia coli from the vector pKK 223 caused an increase in bacterial galactosyltransferase activity associated with lipopolysaccharide biosynthesis. As shown in Table 1, the increased enzyme activity did not show

Table 1. Expression of a putative galactosyltransferase modifier cDNA clone in $E$. coli strain JM109

Values reported are means \pm S.D. of two experimental determinations performed in duplicate. Galactosyltransferase specific activity is expressed as nmol of galactose incorporated $/ \mathrm{h}$ per $\mathrm{mg}$ of protein using $10 \mathrm{mg}$ of ovalbumin as acceptor glycoprotein.

Experimental conditions

JM 109

JM109 pKK $223\left(\mathrm{GT}^{-}\right)^{*}$

- IPTG $\dagger$

+ IPTG

JM109 pKK $223\left(\mathrm{GT}^{+}\right)_{+}^{+}$

- IPTG

+ IPTG

$+10 \mathrm{~mm}-\mathrm{GlcNAc}$

$+10 \mathrm{~mm}-\mathrm{GlcNAc} / 5 \mu \mathrm{M}$ -

$\alpha$-lactalbumin

$+10 \mathrm{~mm}-\mathrm{Glc}$

$+10 \mathrm{~mm}-\mathrm{Glc} / 5 \mu \mathrm{M}-$ $\alpha$-lactalbumin

* The expression vector pKK 223 containing the cDNA in the $3^{\prime}-5^{\prime}$ orientation relative to the lac $Z$ gene promoter.

+ The lac $Z$ gene gratuitous inducer isopropyl $\beta$-D-thioglucopyranoside.

‡ The expression vector pKK 223 containing the cDNA in the $5^{\prime}-3^{\prime}$ orientation relative to the lac $Z$ gene promoter. 
specificity for $\alpha$-lactalbumin upon affinity chromatography [3], nor was substrate specificity altered from $N$ acetylglucosamine to glucose in the presence of $\alpha$ lactalbumin [4]. The bacterial lysate with increased galactosyltransferase activity did not compete for binding to antiserum to bovine galactosyltransferase in an immune precipitation reaction. Further support for this conclusion has also been put forward by Lopez \& Shur [5] comparing the two reported galactosyltransferase cDNAs $[2,6]$ in Northern blot analysis of lactating mammary gland, $\mathrm{P} 4 \mathrm{~S}$ and $\mathrm{F} 9$ embryonic carcinoma cells.

The size of the mRNA identified by Northern blot in Fig. 1 of [1] is also in error. Further review of the agarose gel migration as well as that determined elsewhere [5] place the actual size of the galactosyltransferase enzyme modifier cDNA at approx. $4.5 \mathrm{~kb}$.

Received 21 July 1989
Michael G. HUMPHREYS-BEHER

Department of Oral Biology, College of Dentistry, University of Florida, J. Hillis Miller Health Center, Box J-424, Gainesville, FL 32610, U.S.A.

1. Humphreys-Beher, M. G. (1988) Biochem. J. 249, 357-362

2. Humphreys-Beher, M. G., Bunnell, B., Van Tuinen, P., Ledbetter, D. H. \& Kidd, V. J. (1986) Proc. Natl. Acad. Sci. U.S.A. 83, 8919-8922

3. Trayer, I. P. \& Hill, R. L. (1979) J. Biol. Chem. 246, 6666-6671

4. Ebner, K. E. (1973) Enzymes 3rd Ed. 9, 363-377

5. Lopez, L. C. \& Shur, B. D. (1988) Biochem. Biophys. Res. Commun. 156, 1223-1229

6. Shaper, N. G., Shaper, J. H., Meuth, J. L., Fox, J. L., Chang, H., Kirsch, L. R. \& Hollis, G. F. (1986) Proc. Natl. Acad. Sci. U.S.A. 83, 1573-1577 